\title{
Merkkeuze bij consumenten
}

\author{
B. WIERENGA
}

Samenvatting Bij iedere aankoop van een produkt waarvan meer dan één merk wordt aangeboden, moet de consument een keuze doen uit de beschikbare merken. Welk merk wordt gekozen is afhankelijk van: eerder gekochte merken, de winkel waarin wordt gekocht en marketing variabelen zoals prijs en reclame.

De invloed van eerder gekochte merken kan worden weergegeven door merkkeuzemodellen, waarvan er in het artikel enkele worden besproken. Deze modellen worden vervolgens toegepast op empirische gegevens. Hierdoor wordt inzicht verkregen in de aard van het merkkeuzeproces. Voor dezelfde empirische gegevens wordt ook de invloed op de merkkeuze onderzocht van winkelkeuze en marketing variabelen.

\section{Inleiding}

Vandaag aan de dag worden de meeste produkten, met name consumentengoederen, verkocht onder merk. Een merk biedt de koper van het produkt de garantie van een aantal constante eigenschappen, terwijl het de aanbieder van het produkt (fabrikant of detaillist) het voordeel biedt dat zijn produkt in de markt wordt onderscheiden van concurrerende produkten. Het merk is vaak het aangrijpingspunt van het marktbeleid.

Doorgaans worden er van één produkt meerdere merken aangeboden. Een consument moet dan bij iedere aankoop een keus doen uit de beschikbare merken. Inzicht in de wijze waarop deze keuzen worden gemaakt en met betrekking tot de factoren die daarbij van invloed zijn is belangrijk voor de aanbieder van het produkt. Hij kan daarmee bepaalde ontwikkelingen in een markt die de positie van het eigen merk raken, vroegtijdig signaleren en eventueel door aanpassingen in het marktbeleid trachten bij te sturen. Ook in het meer algemene kader van kennis omtrent het consumentengedrag is inzicht in het merkkeuzegedrag van belang.

Dit artikel beschrijft, min of meer in de vorm van een case-study, hoe aan de hand van een hoeveelheid empirisch materiaal, gebruik makend van diverse modellen en statistische methoden, getracht is dit merkkeuzegedrag te analyseren bij een aantal frequent gekochte produkten in de voedingsmiddelensfeer. De vraagstelling hierbij luidt: hoe maakt de consument zijn merkkeuzen? Nader toegespitst werden de volgende aspecten onderzocht.

1. Wat is de invloed van eerder gekochte merken op de merkkeuze? Als bij de voorgaande aankoop een bepaald merk is gekocht, bestaat er dan een relatief grote kans, dat dit merk bij de volgende aankoop weer wordt gekozen?

Wordt deze kans groter naarmate men vaker achtereen hetzelfde merk heeft gekocht?

2. Wat is de invloed van de winkelkeuze op de merkkeuze?

3. Wat is de invloed van marketingvariabelen, zoals prijs en reclame op de merkkeuze? 
Het onderzoek houdt zich uitsluitend bezig met merkkeuze als waar te nemen fenomeen. Er is niet expliciet aandacht geschonken aan wat zich daarbij afspeelt in het hoofd van de consument, d.w.z. hoe zijn (haar) percepties, attitudes, en motivaties, met betrekking tot de diverse merken veranderen tijdens het merkkeuzeproces.

Het gebruikte empirisch materiaal wordt gevormd door de koopgeschiedenissen van leden van het Attwood consumentenpanel (een representatieve steekproef uit de Nederlandse huishoudingen). De onderzochte produkten zijn: bier, fopro (een pseudoniem voor een produkt in de voedingsmiddelensfeer) en margarine. De aankopen vonden plaats in de jaren 1967 en 1968. De aantallen huishoudingen in het onderzoek zijn: 627 voor bier, 672 voor fopro en 1059 voor margarine. De gemiddelde aantallen aankopen per huishouding in de waarnemingsperiode zijn respectievelijk 43, 88 en 123. Een veel uitgebreidere beschrijving van het onderzoek en de resultaten is te vinden in WIERENGA [8].

Daar worden ook de gebruikte methoden uitvoeriger beschreven en worden de uitkomsten vergeleken met resultaten van andere onderzoekers.

In de volgende paragrafen worden de 3 bovenvermelde vragen achtereenvolgens aan de orde gesteld. De vraag naar de invloed van voorgaande aankopen zal hierbij de meeste aandacht krijgen. Er zal tamelijk uitvoerig aandacht worden besteed aan stochastische modellen waarmee het merkkeuzegedrag van consumenten kan worden beschreven. Bij ieder onderdeel worden zowel de gebruikte methoden als de verkregen resultaten vermeld. Het artikel eindigt met een korte slotbeschouwing.

\section{De invloed van eerder gekochte merken}

\subsection{Merkkeuze als een stochastisch proces}

Consumentengedrag is doorgaans een stochastische aangelegenheid. Dit geldt ook met betrekking tot het merkkeuzegedrag. Laat $X_{t}$ aangeven het merk, dat een bepaalde consument kiest op aankooptijdstip $t$. De index $t$ heeft betrekking op het volgnummer van de aankoop. De eerste aankoop van een consument correspondeert met $t=1$, de tweede met $t=2$, etc. Er is dus geen directe relatie met kalendertijd. Verder wordt er ook met verschillen in de gekochte hoeveelheid per kooptijdstip geen rekening gehouden. Als er $m$ verschillende merken in een markt zijn, aangeduid met de nummers $l \mathrm{t} / \mathrm{m} m$, dan kan $X_{t} m$ verschillende waarden aannemen.

Het merkkeuzeproces

$$
X_{1}, X_{2}, \ldots, X_{t}, \ldots
$$

ook aan te geven als $\left\{X_{t}\right\}$ is dus een stochastisch proces met een discrete toestandsruimte en een discrete tijdparameter. In het algemeen zal de uitkomst van dit merkkeuzeproces op tijdstip $t$ afhankelijk zijn van voorgaande realisaties. De kans dat op tijdstip $t$ merk $i$ wordt gekozen, gegeven de merken die zijn gekozen bij de voorgaande aankopen, kan worden aangegeven als

$$
P\left(X_{t}=i \mid x_{t-1}, x_{t-2}, x_{t-3}, \ldots\right)
$$


Hier en bij alles wat volgt dient de kans, dat een bepaald merk wordt gekozen conditioneel te worden opgevat: gegevens dat er een aankoop van het betreffende produkt plaatsvindt.

Uitdrukking (1) is erg algemeen en laat toe, dat de kansverdeling over de merken op een bepaald kooptijdstip afhankelijk is van de hele koopgeschiedenis van de betreffende consument. In de praktijk zal men de relatie tussen de kans op een bepaald merk en de voorgaande aankopen nader moeten specificeren. De verschillende merkkeuzemodellen, die ontwikkeld zijn in de marketing literatuur zijn zulke specificaties.

Het toetsen of deze modellen in overeenstemming zijn met de merkkeuzeprocessen, zoals deze in werkelijkheid zijn waargenomen geeft dus inzicht in dit aspect van het merkkeuzegedrag. In het volgende wordt dit voor een drietal typen modellen gedaan: het Bernoulli model, het Markov model en het Lineair Leermodel.

In veel gevallen worden bij deze merkkeuzemodellen slechts 2 merken in een markt onderscheiden. Deze duiden we aan als merk 1 en merk 0 . Het merk waarin men speciaal geīnteresseerd is, bijvoorbeeld het eigen merk, kan merk 1 genoemd worden, alle andere merken in de markt zijn dan merk 0 . De kans, dat in deze 2-merken markt merk 1 wordt gekozen, wordt aangeduid als $p$, de kans op merk 0 is dan $(1-p)$.

Deze vaak noodzakeiijke stilering tot een 2-merken markt heeft uiteraard consequenties. Als b.v. in een markt met meer merken een Markov model geldt en alle merken op één na worden samengenomen dan geldt i.h.a. voor de ontstane 2-merken markt het Markov model niet.

Een zeer uitvoerige behandeling van merkkeuzeprocessen en bijbehorende toetsingsprocedures is te vinden in MASSY [7], hieraan is veel van de hier behandelde theorie ontleend.

\subsection{Merkkeuzemodellen}

\subsubsection{Bernoulli model}

In het Bernoulli model wordt verondersteld, dat een consument altijd met dezelfde kans merk 1 kiest, ongeacht de koopgeschiedenis. Formule (1) gaat hier over in

$$
P\left(X_{t}=1 \mid x_{t-1}, x_{t-2}, x_{t-3}, \ldots\right)=P\left(X_{t}=1\right)=p
$$

De achtereenvolgende aankopen vormen dan een onafhankelijk Bernoulli proces.

Van de hier te bespreken modellen maakt het Bernoulli model de meest vergaande veronderstelling met betrekking tot de invloed van voorgaande aankopen: het neemt aan dat deze invloed volledig afwezig is. Het Bernoulli model kan daarom een model van de orde nul worden genoemd. Mocht in een empirische situatie blijken, dat het Bernoulli model een goede beschrijving geeft van het waargenomen merkkeuzeproces, dan heeft het geen zin nog aandacht te besteden aan modellen, zoals het Markov model en het Lineair Leermodel, die invloed van voorgaande aankopen veronderstellen. 


\subsubsection{Markov modellen}

Bij het Markov model wordt verondersteld, dat bij de merkkeuze op een bepaald aankooptijdstip alleen het meest recente deel van de koopgeschiedenis van invloed is. Bij een eerste orde Markov model neemt (1) de vorm aan

$$
P\left(X_{t}=i \mid x_{t-1}, x_{t-2}, x_{t-3}, \ldots\right)=P\left(X_{t}=i \mid x_{t-1}\right)
$$

en wordt er dus aangenomen, dat alleen de laatste aankoop effect heeft. Alle daarvoor gedane merkkeuzen doen er niet toe.

De kans

$$
p_{i j}=P\left(X_{t}=j \mid X_{t-1}=i\right)(i, j=0,1)
$$

wordt een overgangskans genoemd.

De overgangskansen kunnen worden gerangschikt in de transitiematrix $P$, die bij een 2-merken markt de vorm heeft:

$$
P={ }_{1}^{0}\left[\begin{array}{cc}
0 & 1 \\
p_{00} & p_{01} \\
p_{10} & p_{11}
\end{array}\right]
$$

Uiteraard moet gelden $p_{i_{0}}+p_{i_{1}}=1(i=0,1)$

Wanneer $p_{01}=p_{11}=p$ zijn we terug in de situatie van het Bernoulli model, dit is dus een bijzonder geval van het Markov model. De overgangskansen kunnen worden geschat uit de relatieve frequenties waarmee de verschillende typen transities optreden in de waargenomen koopgeschiedenissen. Zij geven interessante informatie over de bewegingen in een markt.

Een tweetal eigenschappen van het Markov merkkeuzemodel, direct volgend uit de algemene theorie met betrekking tot Markov ketens zijn bijzonder nuttig. Zie b.v. KeMENy en SNell [6].

(i) Als $\alpha(t)$ de (rij-)vector van marktaandelen op tijdstip $t$ is, dan geldt: $\alpha(t+1)=\alpha(t) P$

(ii) Het Markov-proces kent een evenwichtsverdeling. De vector van evenwichtsmarktaandelen $\alpha(e)$ kan worden berekend uit:

$\alpha(e)=\alpha(e) P$

Hierbij doet het er niet toe met welke marktaandelen gestart wordt. De evenwichtsmarktaandelen hebben een belangrijke marketing interpretatie: het zijn de waarden waar de marktaandelen naar toe gaan als de beweging in de markt dezelfde blijft, d.i. gekarakteriseerd door de transitiematrix $P$.

Tot nu toe hebben we ons met het eerste orde Markov model bezig gehouden. Uitbreiding tot hogere orde modellen, waarbij een groter aantal voorgaande aankopen van invloed is op de merkkeuze ligt voor de hand. 
Bij voorbeeld bij een tweede orde model geldt

$$
P\left(X_{t}=i \mid x_{t-1}, x_{t-2}, x_{t-3}, \ldots\right)=P\left(X_{t}=i \mid x_{t-1}, x_{t-2}\right)
$$

en heeft zowel de laatste als de op één na laatste aankoop invloed op de merkkeuze.

Een ander aspect is, dat er stationariteit is verondersteld: de overgangskansen zijn constant in de tijd (in (4) heeft $p_{10}$ niet de index $t$ ). Zonder deze stationariteitsveronderstelling (althans voor perioden van redelijke lengte) zou het Markov model veel van zijn aantrekkelijkheid verliezen. Bijvoorbeeld het berekenen van evenwichtsmarktaandelen is dan niet meer mogelijk.

\subsubsection{Homogene versus Heterogene modellen}

Tot nu toe is impliciet aangenomen dat iedere consument dezelfde modelparameters heeft. Bij het Bernoulli model impliceert deze veronderstelling dat iedere consument dezelfde $p$-waarde heeft. Dit kan het Homogeen Bernoulli model worden genoemd. Aangezien dit model niet erg realistisch is - het veronderstelt dat alle consumenten alle merken in dezelfde verhoudingen kopen - wordt hieraan verder geen aandacht besteed.

Bij het Heterogeen Bernoulli model kunnen verschillende consumenten verschillende (constante) $p$-waarden hebben. We kunnen dan spreken van de verdeling van $p$ in de consumentenpopulatie. De kansdichtheid hiervan kan worden aangegeven als $f(p)$. In een empirische situatie is het belangrijk deze verdeling te kennen. Hiervoor kan soms de beta-verdeling worden benut. De betaverdeling heeft als waardengebied het $[0,1]$ interval (wat hier nodig is) en de kansdichtheid ervan kan een groot aantal verschillende vormen aannemen.

Bij het Markov model betekent homogeniteit dat iedere consument dezelfde matrix van overgangswaarschijnlijkheden heeft. Dit is een minder stringente beperking dan homogeniteit bij het Bernoulli model, omdat verschillende consumenten nu toch verschillende p-waarden kunnen hebben (al naar gelang de koopgeschiedenis). Vooral bij hogere orde Markovmodellen neemt het aantal mogelijke verschillende $p$-waarden snel toe.

Ook van het Markov model kan een heterogene versie worden ontwikkeld, d.w.z. een Markov model, waarbij verschillende consumenten verschillende transitiematrices hebben.

In het geval van een eerste orde Markov model heeft iedere consument een transitiematrix $P$ :

$$
P=\begin{aligned}
& 0 \\
& 1
\end{aligned}\left[\begin{array}{lr}
0 & 1 \\
p_{00} & \left(1-p_{00}\right) \\
\left(1-p_{11}\right) & p_{11}
\end{array}\right]
$$

gekarakteriseerd door 2 parameters $p_{00}$ en $p_{11}$. In het werk dat tot nu toe aan dit model verricht is, bleek dit te moeilijk handelbaar te zijn. Als $p_{11}$ en $p_{00}$ kunnen variëren zonder een exacte relatie tussen deze beide parameters, is er een bivariate ver- 
deling nodig om de verdeling van $P$ in de populatie te beschrijven. Dit maakt het erg gecompliceerd. Dit is bij het eerste orde Markov model reeds een groot probleem. Toepasbare versies van hogere orde heterogene Markov modellen ontbreken geheel.

\subsubsection{Het Lineair Leermodel}

Een model, dat tot op zekere hoogte homogeniteit en heterogeniteit combineert is het Lineair Leermodel. Bij dit model zijn namelijk de modelparameters voor alle consumenten dezelfde (homogeniteit), maar hebben in het algemeen verschillende consumenten op hetzelfde tijdstip verschillende kansen op een merk 1 aankoop (heterogeniteit). Deze kansen kunnen tussen een ondergrens en een bovengrens alle mogelijke waarden aannemen. Het Lineair Leermodel is afkomstig uit de mathematische psychologie, waar het veel is gebruikt om leerexperimenten (b.v. met ratten in T-gangen) te beschrijven. Een klassieke behandeling is Bush en Mosteller [3].

Bij het Lineair Leermodel wordt verondersteld, dat de kans om merk 1 te kopen op aankooptijdstip $t$, aangegeven door $p_{t}$, een lineaire functie is van de kans op een merk 1 aankoop op tijdstip $(t-1)$. Er zijn twee verschillende functies, waarvan de ene van toepassing is als op tijdstip $(t-1)$ merk 1 is gekocht en de andere als op tijdstip $(t-1)$ merk 0 is gekocht.

Aldus geldt

$$
p_{t}=\alpha+\beta+\lambda p_{t-1} \quad \text { (koopoperator) }
$$

en

$$
p_{t}=\alpha+\lambda p_{t-1} \quad \text { (afwijzingsoperator) }
$$

Het verband tussen $p_{t-1}$ en $p_{t}$ zal nooit negatief zijn: $\lambda>0$. Aangezien $p_{t \rightarrow 1}$ en $p_{t}$ altijd in het $[0,1]$ interval dienen te liggen geldt voor de parameters de volgende beperking

$$
0 \leqslant(\alpha+\beta+\lambda) \leqslant 1
$$

De operatoren (7) en (8) van het Lineair Lecrmodel werken op het niveau van de individuele consument. In het algemeen zullen op een bepaald tijdstip $t$ verschillende consumenten verschillende $p_{t}$-waarden hebben. De parameters van het Lineair Leermodel $\alpha, \beta$ en $\lambda$ zijn echter dezelfde voor alle consumenten.

Het Lineair Leermodel kan ook in de notatie van een stochastisch proces worden geschreven. Formule (1) gaat hier over in

$$
P\left(X_{t}=1 \mid x_{t-1}, x_{t-2}, x_{t-3}, \ldots\right)=P\left(X_{t}=1 \mid x_{t-1}, p_{t-1}\right)=p_{t}=\alpha+\beta x_{t-1}+\lambda p_{t-1}
$$

De hele koopgeschiedenis tot aan $(t-1)$ wordt dus gerepresenteerd door $p_{t-1}$. Aangezien $x_{t-1}$ de waarden 1 en 0 kan aannemen, omvat (10) zowel (7) als (8).

Herhaalde toepassing van (10) levert bij het teruggaan van $k$ aankopen

$$
p_{t}=\alpha \sum_{j=0}^{k-1} \lambda^{j}+\beta \sum_{j=0}^{k-1} \lambda^{j} x_{t-j-1}+\lambda^{k} p_{t-k}
$$


Uit deze schrijfwijze van het Lineair Leermodel is duidelijk dat het effect van een merkkeuze die $j$ aankopen geleden gedaan is, evenredig is met $\lambda^{(j-1)}$. Aangezien in het algemeen $0<\lambda<1$, neemt de invloed van voorgaande aankopen op de merkkeuze dus exponentieel af naarmate de aankopen langer geleden gedaan zijn. Dit is wat ook intuittief verwacht wordt voor de aankopen in werkelijkheid: naarmate een aankoop langer geleden is, zal een consument deze zich minder goed herinneren en zal het effect kleiner zijn. Ook het geleidelijk afnemen van deze invloed spreekt intuïtief aan, i.t.t. het abrupt eindigen van het effect van voorgaande merkkeuzen na 1 of 2 aankopen, zoals in het eerste, resp. tweede orde Markov model.

Er kan worden afgeleid, dat in het Lineair Leermodel $p$ nooit beneden een ondergrens $p_{L}=\alpha /(1-\lambda)$ kan dalen en nooit boven een bovengrens $p_{U}=(\alpha+\beta) /(1-\lambda)$ kan stijgen. Verder is er een evenwichtswaarde $p_{E}=\alpha /(1-\beta-\lambda)$, d.i. de waarde waar naar toe $p_{t}$ tendeert voor grote $t . p_{E}$ heeft de marketing interpretatie van het lange termijn marktaandeel.

Een andere eigenschap van het Lineair Leermodel is, dat het twee eerder behandelde modellen als bijzondere gevallen omvat.

Voor $\lambda=1$ en $\alpha=\beta=0$ gaat het Lineair Leermodel over in het Bernoulli model:

$$
p_{t}=p_{t-1}
$$

en voor $\lambda=0$ hebben we het homogeen eerste orde Markov model met transitiematrix:

$$
\begin{aligned}
& 0 \\
& 1\left[\begin{array}{cc}
(1-\alpha) & \alpha \\
(1-\alpha-\beta) & \alpha+\beta)
\end{array}\right]
\end{aligned}
$$

\subsection{Confrontatie van de merkkeuzemodellen met de waargenomen merkkeuzeprocessen}

\subsubsection{Toetsen voor het Bernoulli model}

In het volgende zullen toetsingsprocedures worden behandeld en uitgevoerd die dienen om te onderzoeken of de waargenomen merkkeuzeprocessen in overeenstemming zijn met de hiervoor behandelde merkkeuzemodellen. In deze subparagraaf geschiedt dat voor het Bernoulli model, in de twee volgende voor respectievelijk het Markov model en het Lineair Leermodel. In [8] is verder nog een simulatiestudie beschreven, uitgevoerd ter verificatie van de toetsingsresultaten.

$\mathrm{Om}$ te onderzoeken of de waargenomen merkkeuzeprocessen in overeenstemming zijn met het Bernoulli model werden een drietal toetsen uitgevoerd.

(i) Een run-toets

De koopgeschiedenis van een bepaalde huishouding $\mathrm{Hl}$ (huishouding en consument worden hier door elkaar gebruikt) zou er als volgt uit kunnen zien:

0000011100111110000 
Een andere huishouding, $\mathrm{H} 2$, die ook 20 aankopen heeft gedaan waarvan 8 merk 1 aankopen zou de koopgeschiedenis

00101000101001010011

kunnen hebben. Voor beide huishoudingen is de fractie merk 1 aankopen .4. Bij de run-toets wordt onderzocht of de kans op een merk 1 aankoop constant is tijdens de koopgeschiedenis en de aankopen onafhankelijk zijn, dan wel of deze kans verandert al naar gelang de gekozen merken. Als er een neiging tot merktrouw bestaat, zal de kans op een merk 1 aankoop relatief groot zijn na een merk 1 aankoop en klein na een merk 0 aankoop. In dat geval hebben de enen en nullen de neiging tot ,kleven" en vertoont de koopgeschiedenis een beeld als dat van huishouding H1. Beīnvloeden opeenvolgende aankopen elkaar niet dan is meer het beeld van huishouding $\mathrm{H} 2$ te verwachten.

De toetsingsgrootheid bij de run-toets is het aantal runs in de koopgeschiedenis, waarbij een run is gedefinieerd als een ononderbroken serie aankopen van hetzelfde merk. Voor korte sequenties bestaan er tabellen, voor langere koopgeschiedenissen kan een benadering met de normale verdeling worden toegepast. Voor literatuur over de run-toets zie b.v. BradLeY [2, hfd. 11].

In de als voorbeeld gegeven koopgeschiedenissen is het aantal runs respectievelijk 5 en 14. Uit de tabel voor de run-test blijkt dat voor het geval met 20 aankopen, waarvan 8 merk 1, de linkszijdig kritieke waarde van het aantal runs 6 is $(\alpha=.05)$, zodat we voor huishouding $\mathrm{Hl}$ de hypothese van een constante kans op een merk 1 aankoop verwerpen. Hier blijkt de kans op een merk 1 aankoop dus groter te zijn na een merk 1 aankoop en kleiner na een merk 0 aankoop: deze huishouding vertoont merktrouw.

Voor alle huishoudingen werd op deze wijze de run-toets uitgevoerd. Voor bier leidde dit tot verwerping van de constante $p$-hypothese bij $58 \%$ van de huishoudingen, voor fopro bij $73 \%$ en voor margarine bij $71 \%$. Dit betekent dat het heterogeen Bernoulli model met de veronderstelling van geen invloed van voorgaande aankopen althans voor het merendeel van de huishoudingen niet in overeenstemming is met het werkelijk koopgedrag.

De run-toets heeft een tweetal beperkingen. (a) Als het aantal nullen of enen erg klein is, is de test niet uit te voeren. (b) Het onderscheidingsvermogen, vooral bij kortere koopgeschiedenissen, is bescheiden. Er wordt namelijk getoetst tegenover een alternatief van le orde afhankelijkheid (merk op dat bier gemiddeld de kortste koopgeschiedenissen heeft en het laagst percentage verwerpingen in de run-toets). Daarom werden om het Bernoulli model te toetsen nog twee andere toetsen uitgevoerd, die beide - in tegenstelling tot de run-toets - niet worden toegepast op de koopgeschiedenissen van individuele huishoudingen, maar op dit van de hele consumentenpopulatie. (ii) Een toets op gelijke koopwaarschijnlijkheden.

Als het merkkeuzeproces volgens het Bernoulli model verloopt hebben 2 koopgeschiedenissen van dezelfde lengte en met hetzelfde aantal enen (en nullen) dezelfde kans om door een merk 1 aankoop gevolgd te worden. Dit is als volgt te in zien. 
Veronderstel dat de verdeling van de $p$-waarden over de huishoudingen de kansdichtheid $f(p)$ heeft.

Veronderstel verder dat we van een huishouding de koopgeschiedenis $x$ waargenomen hebben.

Met behulp van de Stelling van Bayes kan dan de posteriori kansdichtheid van $p$ (aangegeven door $f_{1}(p)$ ) voor deze huishouding worden geschreven als

$$
f_{1}(p \mid x)=\frac{p(x \mid p) f(p)}{\int_{0}^{1} p(x \mid p) f(p) \mathrm{d} p}
$$

Hieruit blijkt, dat als de waarschijnlijkheid (likelihood)

$$
P(x \mid p)
$$

van 2 koopgeschiedenissen dezelfde is voor elke $p$, de posteriori kansverdelingen van $p$ behorende bij deze 2 koopgeschiedenissen ook gelijk zijn. In het geval van het heterogeen Bernoulli model zijn de achtereenvolgende aankopen onafhankelijke Bernoulli trekkingen. Iedere koopgeschiedenis met vaste lengte $n$ en $k$ enen heeft dan dezelfde waarschijnlijkheid voor gegeven $p$, nl.

$$
p^{k}(1-p)^{n-k}
$$

en derhalve hebben koopgeschiedenissen met $k$ enen bij $n$ aankopen dezelfde posteriori kans op een merk 1 aankoop, ongeacht de plaatsing van de $k$ enen in de koopgeschiedenis. Dit geldt voor alle $k$ en dus hebben koopgeschiedenissen van dezelfde lengte en met hetzelfde aantal enen dezelfde kans om door een merk 1 aankoop gevolgd te worden. Hierop berust de toets op gelijke koopwaarschijnlijkheden.

In het onderzoek werd voor $n 4$ genomen en werd onderzocht of binnen de 3 groepen koopgeschiedenissen met respectievelijk 1, 2 en 3 enen voor de verschillende sequenties de kans om door een merk 1 aankoop gevolgd te worden inderdaad gelijk is.

Een typisch resultaat voor de groep met 1 merk 1 aankoop voor een bepaald merk fopro is Tabel 1. (Aangezien het ondoenlijk is om in dit artikel alle resultaten voor alle produkten en merken te geven, wordt vaak volstaan met illustratieve resultaten voor een bepaald geval).

Tabel 1. Kans op een merk 1 aankoop na 4 verschillende koopsequenties, alle met 1 één en 3 nullen

\begin{tabular}{lll}
\hline sequentie & \multicolumn{2}{c}{ kans (geschat) dat de volgende aankoop is: } \\
& 0 & 1 \\
\hline 0001 & .50 & .50 \\
0010 & .82 & .18 \\
0100 & .70 & .30 \\
1000 & .86 & .14 \\
\hline
\end{tabular}


Het blijkt duidelijk dat voor deze sequenties de kansen om door een merk 1 aankoop gevolgd te worden niet gelijk zijn. Als de enige merk 1 aankoop in de koopsequentie de meest recente aankoop is, is de kans op een merk 1 aankoop .50, als de merk 1 aankoop 3 aankopen geleden is, is die kans slechts .14. Dit duidt op invloed van vorige merken. Dergelijke tabellen kunnen ook worden gemaakt voor koopgeschiedenissen ter lengte 4 met 2 enen ( 6 verschillende sequenties mogelijk) en 3 enen ( 4 sequenties mogelijk). De hypothese van gelijke kansen op een merk 1 aankoop voor de sequenties binnen een tabel wordt getoetst met een $\chi^{2}$-toets. Hierbij worden de sequenties van alle huishoudingen in één $\chi^{2}$-tabel verzameld. Het bleek dat in vrijwel alle gevallen de betreffende koopwaarschijnlijkheden, evenals in het bovenstaande voorbeeld (voor Tabel 1 werd gevonden: $\chi_{3}^{2}=15.3$ ) niet gelijk waren. Dit impliceert verwerping van het Bernoulli model. Dat hier de $\chi^{2}$-toets mag worden toegepast ondanks de heterogeniteit m.b.t. $p$ kan als volgt worden ingezien. Onder de nulhypothese van een Bernoulli proces is de $p$-waarde van een huishouding die één van de 4 sequenties $0001,0010,0100$ en 1000 te zien heeft gegeven een trekking uit de verdeling met kansdichtheidsfunctie $f_{1}(p)$. De kans, dat deze huishouding als volgende aankoop merk 1 zal kiezen is dus

$$
\int_{0}^{1} \operatorname{prob}(1 \mid p) f_{1}(p) \mathrm{d} p=\int_{0}^{1} p f_{1}(p) \mathrm{d} p=E p
$$

\section{d.i. de verwachtingswaarde van de posteriori verdeling.}

Iedere huishouding met 1 van de 4 genoemde koopgeschiedenissen koopt dus bij de eerstvolgende aankoop merk 1 met kans $E p$ en merk 0 met kans $(1-E p)$. Voor de waarnemer, die uiteraard de echte $p$-waarden van de huishoudingen niet kent, is onder $H o$ de situatie dus equivalent met trekkingen uit een Bernoulli verdeling met kans $E p$ op succes. We beschouwen hier steeds 1 aankoop van een groot aantal huishoudingen, dit is principieel anders dan wanneer er eerst 1 huishouding wordt getrokken, waarvan vervolgens een groot aantal achtereenvolgende aankopen worden bekeken. In het laatste geval doet de variabiliteit m.b.t. $p$ er wel toe. Voor een nadere verantwoording van deze toets, zie MASSY et al. [7, hoofdstuk 3].

Uit de theorie m.b.t. deze toets is duidelijk, dat strikt genomen van iedere huishouding slechts één sequentie van 5 aankopen als waarneming mag worden gebruikt. Anders is er niet meer sprake van een apriori verdeling van $p$. Bij de als voorbeeld genoemde toepassing zijn in verband met de wenselijkheid van een voldoend groot aantal waarnemingen wel meerdere koopsequenties van dezelfde huishoudingen gebruikt. Als de verdeling van $p$ niet teveel wijzigt hetgeen voor de onderzochte tamelijk stabiele markten aannemelijk is, lijken de schadelijke gevolgen hiervan beperkt.

(iii) Een toets op gelijke relatieve frequenties van koopsequenties.

Bij deze toets wordt niet beschouwd de kans op een merk 1 aankoop na een bepaalde koopsequentie (zoals bij de voorgaande toets), maar de frequentie van het voorkomen van die sequentie zelf.

Nemen we weer koopsequenties ter lengte 4 , dan is de kans, dat een volgens het 
Bernoulli model kopende huishouding met parameter $p$ de sequentie 1000 te zien zal geven

$$
p(1-p)^{3}
$$

De verwachte fractie van deze sequentie in alle koopsequenties ter lengte 4 van alle huishoudingen is

$$
\int_{0}^{1} p(1-p)^{3} f(p) \mathrm{d} p
$$

Voor de 3 andere mogelijke sequenties met 1 merk 1 aankoop en 3 merk 0 aankopen nl. 0100,0010 en 0001 , is deze verwachte fractie echter even groot. Ook van de groepen met 2, respectievelijk 3 enen in een koopgeschiedenis ter lengte 4 moeten de individuele sequenties even vaak voorkomen. Deze eigenschap van een Bernoulli merkkeuzeproces kan empirisch worden getoetst. Tabel 2 geeft een voorbeeld van verkregen resultaten, wederom voor het produkt fropo.

Tabel 2. Werkelijke en verwachte frequenties van 4 verschillende koopsequenties, alle met 1 én en 3 nullen

\begin{tabular}{lll}
\hline & frequentie & \\
\cline { 2 - 3 } sequentie & werkelijk & verwacht \\
\hline 0001 & 366 & 323.6 \\
0010 & 277 & 323.6 \\
0100 & 276 & 323.6 \\
1000 & 376 & 323.6 \\
\hline
\end{tabular}

In deze tabel blijken de frequenties waarmee de 4 verschillende koopsequenties voorkomen niet gelijk te zijn $\left(\chi_{3}^{2}=27.8\right)$. Ook in alle andere gevallen werd de hypothese van gelijke kansen van de sequenties binnen een groep verworpen. Hieruit blijkt dus weer, dat het Bernoulli model de merkkeuzeprocessen niet goed beschrijft. Een algemeen verschijnsel, ook al waarneembaar in Tabel 2 , is dat sequenties waarin de merk 1 en merk 0 aankopen onderling in groepjes bijeen staan relatief te vaak voorkomen om in overeenstemming te zijn met een Bernoulli proces en sequenties met enen en nullen door elkaar te weinig. Dit is consistent met het gevondene bij de run-toets.

Bij deze toets mogen slechts elkaar niet overlappende koopsequenties worden gebruikt. Het bleek echter dat het voor het resultaat weinig uitmaakte of overlappende dan wel niet-overlappende sequenties werden gebruikt. De drie gebruikte toetsen, hoewel ze verschillende aspecten van het koopproces in beschouwing nemen, leiden unaniem tot de conclusie, dat de onderzochte merkkeuzeprocessen geen Bernoulli processen zijn. Er is dus een duidelijke invloed van voorgaande aankopen op de merkkeuze.

\subsubsection{Toetsen voor het Markov model}

Toetsingsprocedures bij het Markov model dienen met name om de orde van het 
proces te onderzoeken, d.w.z. om te bepalen hoeveel voorgaande aankopen nog invloed hebben op de merkkeuze. Hierbij worden de bekende procedures van ANDERSON en GOODMAN [1] gebruikt, welke leiden tot $\chi^{2}$-toetsen.

Bij de toets op orde nul werd bijvoorbeeld voor een bepaald merk bier de in Tabel 3 weergegeven transitiematrix gevonden.

Tabel 3. Geschatte énstaps transitiematrix

\begin{tabular}{llll}
\hline & & naar & 1 \\
\cline { 2 - 3 } 0 & 0 & .9047 & .0953 \\
1 & .1178 & .8822 \\
\hline
\end{tabular}

Hieruit blijkt, dat er een groot effect is van de meest recente aankoop: de kans om merk 1 te kopen is .09 na een merk 0 aankoop en .88 na een merk 1 aankoop. De hypothese „er is geen invloed van het laatst gekochte merk" wordt dan ook zeer duidelijk verworpen $\left(\chi_{1}^{2}=3482\right)$.

Bij de toets op orde 1 versus 2 werden de in Tabel 4 gegeven overgangskansen gevonden.

Tabel 4. Geschatte 2-staps overgangskansen

\begin{tabular}{lll}
\hline van & 0 & naar \\
& 0 & 1 \\
\hline 00 & .9414 & .0586 \\
10 & .5462 & .4538 \\
01 & .4403 & .5597 \\
11 & .0712 & .9288 \\
\hline
\end{tabular}

Onder de hypothese dat er geen invloed is van de op één na laatste aankoop, zouden de kansen in de 2e regel gelijk moeten zijn aan die in de eerste regel en de kansen in regel 4 gelijk aan die in regel 3. Dit is duidelijk niet het geval. Voor het bovenste deel van Tabel 4 werd de hypothese verworpen met $\chi_{1}^{2}=423$, voor het onderste deel met $\chi_{1}^{2}=307$.

De volgende stap is het toetsen op orde 2 versus 3. Deze toets kon slechts gedeeltelijk worden uitgevoerd wegens beperkingen in de data. Tabel 5 geeft enkele resultaten.

Tabel 5. Geschatte 3-staps overgangskansen

\begin{tabular}{llll}
\hline van & 0 & naar & 1 \\
\cline { 2 - 3 } 000 & .9776 & .0224 \\
100 & .7923 & .2077 \\
011 & .2620 & .7380 \\
111 & .0252 & .9748 \\
\hline
\end{tabular}


Hieruit blijkt, dat ook de op 2 na laatste aankoop nog een duidelijk effect heeft op de merkkeuze. Merk op dat het effect van een voorgaande aankoop kleiner is, naarmate hij langer is geleden. Een merk 1 als laatste aankoop verhoogt de kans op een merk 1 aankoop met plm. 0.8 (tabel 3), voor de op één na laatste aankoop is dit effect plm. 0.4 (tabel 4) voor de op twee na laatste aankoop plm. 0.2 (tabel 5).

Resultaten voor de andere produkten en merken vertonen globaal hetzelfde beeld als het bovenstaande. Hogere orde toetsen werden door het materiaal niet mogelijk gemaakt, maar het valt te verwachten dat ook van verder terug gelegen aankopen nog een effect - zij het een steeds geringer - is te bespeuren op de merkkeuze.

Als het merkkeuzeproces van deze hoge orde is, gaat het Markov model veel van zijn aantrekkelijkheid verliezen. Het aantal parameters (de overgangskansen) neemt snel toe met de orde van het model en gaat hoge eisen aan het waarnemingsmateriaal stellen.

\section{Een aggregatieprobleem}

De overgangskansen die tot nu toe werden berekend, zijn gebaseerd op de koopgeschiedenissen van alle huishoudingen samen. De onderliggende veronderstelling is daarbij, dat alle huishoudingen dezelfde transitiematrix hebben. Het Markov model zoals het tot nu toe is besproken wordt daarom het Homogeen Markovmodel genoemd.

Wat gebeurt er echter als in werkelijkheid de consumentenpopulatie niet homogeen is, zodat bij het op bovenstaande wijze berekenen van overgangskansen koopgeschiedenissen met verschillende transitiematrices worden geaggregeerd? Het blijkt, dat dit problemen op kan leveren bij het vaststellen van de orde van het merkkeuzeproces.

Veronderstel bijvoorbeeld, dat in werkelijkheid de consumentenpopulatie bestaat uit 2 even grote groepen I en II, die beide volgens het Bernoulli model kopen (een Bernoulli model kan beschouwd worden als een Markov model van de orde nul), maar verschillende waarden voor de Bernoulli parameter $p$ hebben. In groep I kopen alle consumenten merk 1 met $p=.9$, in groep II kopen alle consumenten merk 1 met $p=.2$.

Het valt in te zien (gebruik makend van de Stelling van Bayes), dat als voor de geaggregeerde koopgeschiedenissen van deze 2 groepen samen de eerste orde transitiematrix zou worden berekend, deze er als volgt uit zou zien:

$$
0\left[\begin{array}{cc}
0 & 1 \\
1.72 & .28 \\
.23 & .77
\end{array}\right]
$$

Dit suggereert een duidelijke invloed van de voorgaande aankoop, terwijl in werkelijkheid alle consumenten een merkkeuzeproces van de orde nul hebben.

Dit gevolg van de aggregatie is als volgt te verklaren: de consumenten die als laatste aankoop merk 1 hebben, komen voor het grootste deel uit groep I. En de consumenten uit groep I kopen nu één keer vaker merk 1 dan die uit groep II. Maar het is 
niet zo, dat - overeenkomstig de veronderstelling van het eerste orde Markov model de kans op een merk 1 aankoop van een individuele consument verandert tijdens het koopproces.

Het verschijnsel, dat heterogeniteit in de populatie de orde van het merkkeuzeproces hoger kan doen lijken dan deze in werkelijkheid is, geldt ook voor processen met een hogere orde dan nul.

Vanwege dit heterogeniteitseffect zijn de behandelde orde toetsen ook uitgevoerd voor meer homogene subpopulaties b.v. voor alle huishoudingen met merk 1 als favoriet merk en (voor margarine) voor een aantal individuele huishoudingen. Hoewel er een effect van heterogeniteit te bespeuren was, bleken toch ook binnen deze meer homogene subgroepen de merkkeuzeprocessen van hogere orde te zijn. Terzijde kan worden opgemerkt, dat de in par. 2.3.1 behandelde Bernoulli toetsen expliciet rekening houden met heterogeniteit.

Een ander mogelijk antwoord op het bovenstaande probleem is het ontwikkelen van een expliciet heterogeen Markov model. Zoals werd opgemerkt in 2.2.3 kennen de tot nu toe ontwikkelde versies hiervan aanzienlijke beperkingen. Met de in MASSY et al. [7] beschreven toetsingsprocedure, die op hetzelfde principe berust als de toets op gelijke koopwaarschijnlijkheden voor het Bernoulli model (zie (ii) in 2.3.1) werd vastgesteld dat deze modellen geen goede beschrijving vormen van de onderzochte merkkeuzeprocessen.

\subsubsection{Toetsen en schatten voor het Lineair Leermodel}

Het schatten en toetsen is bij het Lineair Leermodel nogal gecompliceerd. Dit wordt vooral veroorzaakt door heterogeniteit m.b.t. p, d.w.z. het feit, dat verschillende consumenten in het algemeen verschillende (onbekende) $p$-waarden hebben aan het begin van de waarnemingsperiode. $\mathrm{Bij}$ de in dit onderzoek gebruikte methode wordt verondersteld dat deze ,startwaarden" voor $p$ in de consumentenpopulatie een bepaalde verdeling hebben met als eerste 4 momenten $\mu_{1}, \mu_{2}, \mu_{3}$ en $\mu_{4}$. Er kan een theoretische uitdrukking worden gevonden - in $\alpha, \beta, \lambda, \mu_{1}, \mu_{2}, \mu_{3}$ en $\mu_{4}$-voor de relatieve frequentie waarmee iedere individuele sequentie van lengte 4 voorkomt binnen alle (zestien) mogelijke koopsequenties van lengte 5 . Schatting van de leermodelparameters komt dan neer op het vinden van zodanige waarden voor $\alpha, \beta, \lambda, \mu_{1}, \mu_{2}, \mu_{3}$ en $\mu_{4}$ dat de discrepantie tussen theoretische en werkelijke relatieve frequenties zo klein mogelijk is in een chikwadraat betekenis. Het is dus een zgn. minimum chikwadraat schattingsprocedure, zie CRAMER [5, p. 424-434]. Het gevonden minimum dient tevens als toetsingsgrootheid.

Uitvoering van de procedure vereist het minimeren van een niet-lineaire functie in 7 variabelen, waarvoor een iteratieve numerieke techniek werd gebruikt.

Bij deze door MASSY [7, hoofdstuk 5] ontwikkelde methode, kunnen in principe alleen de koopsequenties, gevormd door de eerste 4 aankopen in de waargenomen koopgeschiedenissen als waarnemingen dienst doen. Worden meerdere sequenties ter lengte 4 van dezelfde huishoudingen gebruikt dan bestaat er tussen deze sequenties een afhankelijkheid. 
Als iedere huishouding slechts I waarneming levert, betekent dit dat men met zeer grote consumentenpanels moet werken om voldoende waarnemingen te hebben. Vanwege deze omstandigheid gebruikt men toch vaak meer sequenties van dezelfde huishoudingen met het bovengenoemd bezwaar. Een indicatie dat de afhankelijkheid niet al te storend is, zou kunnen worden ontleend aan het feit dat er niet veel verschil in de resultaten bestaat al naar gelang men overlappende of niet-overlappende sequenties neemt. (In het eerste geval is de afhankelijkheid veel sterker dan in het laatste). Toch blijft de procedure onbevredigend en derhalve wordt er gewerkt aan een andere schattingsmethode voor het Lineair Leermodel, zie WIERENGA [9].

De resultaten voor het Lineair Leermodel verkregen met bovenstaande minimum chikwadraat methode zijn erg goed. In alle gevallen bleken de empirische merkkeuzeprocessen goed door het Lineaire Leermodel te worden beschreven. Een typisch resultaat, voor een bepaald merk bier, is gegeven in Tabel 6.

Tabel 6. Schattingsresultaat voor het Lineair Leermodel

\begin{tabular}{lll}
\hline$\hat{\alpha}=.0168$ & $\hat{\mu}_{1}=.4200$ & $\chi_{8}^{2}=6.20$ \\
$\hat{\beta}=.4034$ & $\hat{\mu}_{2}=.3448$ & \\
$\hat{\lambda}=.5619$ & $\hat{\mu}_{3}=.3071$ & \\
& $\hat{\mu}_{4}=.3057$ &
\end{tabular}

Van deze vier geschatte momenten lijkt $\hat{\mu}_{4}$ relatief te groot om samen de eerste 4 momenten van een kansverdeling op $[0,1]$ te kunnen zijn. Dit heeft te maken met de gesignaleerde tekortkomingen van de schattingsmethode. Uit de lage $\chi^{2}$-waarde blijkt de goede aanpassing. Uit de waarde .4 voor $\hat{\beta}$ blijkt, dat het aanzienlijk verschil maakt voor de merkkeuze of bij de voorgaande aankoop merk 1 dan wel merk 0 werd gekocht. De waarde .5619 voor $\hat{\lambda}$ geeft aan, dat er ook een duidelijke invloed van voorgaande aankopen is, welke praktisch gesproken ongeveer 8 aankopen teruggaat $\left(.5619^{8}=.01\right)$. De $p$-waarden liggen voor dit geval altijd tussen $\hat{p}_{L}=.039$ en $\hat{p}_{U}=.959$, het evenwichtsmarktaandeel is $\hat{p}_{E}=.48$. Het laatste betekent een te verwachten gunstige ontwikkeling voor het betreffende merk, want het lopend marktaandeel is $\mathbf{. 4 2}$.

De numerieke uitkomsten voor de andere gevallen zijn uiteraard verschillend, de goede aanpassing van het Lineair Leermodel is echter algemeen. Dit was min of meer te verwachten, gezien de resultaten bij de eerdere toetsen: bij de Bernoulli toetsen bleek de invloed van voorgaande aankopen reeds duidelijk, bij de Markovtoetsen kwam het karakter van het merkkeuzeproces als een proces van hogere orde met afnemende invloed van verder weg gelegen aankopen naar voren. En een dergelijk proces wordt nu juist door het Lineair Leermodel goed beschreven.

\section{De invloed van de winkel}

Merkkeuzen worden doorgaans gemaakt in winkels. Het is daarom belangrijk te weten of er verband bestaat tussen het keuzegedrag met betrekking tot de winkel, 
waarin de aankoop van het betreffende produkt gedaan wordt en het keuzegedrag met betrekking tot het merk. Een zeker verband is er altijd, veroorzaakt door het feit dat een winkel doorgaans niet alle merken van een produkt voert, zodat de keuze van een winkel de verzameling van merken waaruit gekozen kan worden beperkt. Maar, het is interessant te weten of er daarbovenuit nog een ,,autonome" relatie tussen merkkeuze en winkelkeuze bestaat, zodanig dat consumenten die vaak van winkel veranderen ook vaak van merk veranderen. Een achterliggende oorzaak van zo'n verschijnsel zou een algemene neiging tot verandering kunnen zijn.

Om de samenhang tussen merkkeuze en winkelkeuze te bestuderen werden voor elke huishouding de waarden van een viertal variabelen berekend, te weten:

1. AFAVM = aandeel van het favoriete merk (d.i. het meest gekochte merk) in de aankopen

2. AANTM $=$ aantal verschillende merken dat gekocht werd

3. AFAVW = aandeel van de favoriete winkel (voor het betreffende produkt)

4. AANTW = aantal verschillende winkels waarin het betreffende produkt werd gekocht.

De variabelen hebben betrekking op alle aankopen gedurende de waarnemingsperiode van 2 jaar.

Tussen de corresponderende variabelen voor merk en winkel werden correlatiecoëfficiēnten berekend. Deze zijn weergegeven in Tabel 7.

Tabel 7. Correlatiecoëfficiënten tussen corresponderende merk- en winkelvariabelen

\begin{tabular}{lccc}
\hline & bier & fopro & margarine \\
\hline r(AFAVM, AFAVW) & .35 & .58 & .36 \\
r(AANTM, AANTW) & .47 & .69 & .62 \\
$n$ (steekproefgrootte) & 627 & 672 & 1059 \\
\hline
\end{tabular}

Hieruit blijkt een duidelijke samenhang: huishoudingen met veel merken hebben doorgaans ook veel winkels en huishoudingen met een groot aandeel van het favoriete merk hebben dat doorgaans ook voor de favoriete winkel. Het lijkt onwaarschijnlijk dat deze samenhang in zijn geheel kan worden teruggebracht tot de distributiebeperking, d.w.z. het feit, dat niet iedere winkel alle merken voert. In feite werd de onmogelijkheid daarvan aangetoond voor enkele grote nationale merken (met een distributie van vrijwel $100 \%$ ).

Om de merk-winkel samenhang nader te analyseren werden behalve de 4 reeds genoemde nog 8 andere variabelen gedefinieerd, te weten:

5. WPM = Winkels per merk. Voor iedere huishouding werd voor elk gekocht merk vastgesteld in hoeveel verschillende winkels het werd gekocht en dit getal werd gemiddeld over de verschillende merken.

6. MPW = Merken per winkel. Berekend op dezelfde wijze, mutatis mutandis als WPM. 
7. MVMWV = Merkverandering met winkelverandering: fractie van de merkveranderingen waarbij een winkelverandering optrad.

8. WVMMV $=$ Winkelverandering met merkverandering: fractie van de winkelveranderingen waarbij een merkverandering optrad.

9. GEENV = Geen verandering: fractie van de aankopen waarbij noch merkverandering, noch winkelverandering optrad.

10. MV = Merkverandering: fractie van de aankopen met merkverandering.

11. WV = Winkelverandering: fractie van de aankopen met winkelverandering.

12. MWV = Merk en winkelverandering: fractie van de aankopen met merk én winkelverandering.

Voor elke huishouding werden de waarden voor al deze variabelen vastgesteld. Vervolgens werd voor de 12 variabelen de correlatiematrix berekend en hiervan uitgaande werd een factoranalyse uitgevoerd. Er werd een ,,maximum-likelihood" schattingsmethode toegepast, daarna werd een varimax rotatie van de factoren uitgevoerd. Als illustratie van de verkregen resultaten worden in Tabel 8 de verkregen factorladingen voor bier gegeven. Er werden vier factoren geëxtraheerd. Voor iedere factor zijn in Tabel 8 de drie in absolute waarde grootste factorladingen speciaal aangegeven.

Tabel 8. Factorladingen voor bier

\begin{tabular}{lrrrr}
\hline variabele & \multicolumn{1}{l}{ F1 } & \multicolumn{1}{l}{ F2 } & \multicolumn{1}{l}{ F3 } & \multicolumn{1}{c}{ F4 } \\
\hline 1. AFAVM & -.104 & -.670 & .355 & -.097 \\
2. AANTM & -.237 & .904 & -.164 & .213 \\
3. AFAVW & .616 & -.091 & .371 & -.043 \\
4. AANTW & -.952 & .203 & -.172 & .150 \\
5. WPM & -.688 & -.424 & -.166 & -.290 \\
6. MPW & .289 & .721 & -.186 & -.235 \\
7. MVMWV & -.258 & -.214 & -.112 & .678 \\
8. WVMMV & .142 & .391 & -.141 & .706 \\
9. GEENV & .238 & -.300 & .786 & .038 \\
10. MV & -.027 & .490 & -.667 & .296 \\
11. WV & -.416 & -.009 & -.746 & .213 \\
12. MWV & -.130 & .199 & -.653 & .661 \\
aandeel in variantie & .19 & .22 & .21 & .15 \\
\hline
\end{tabular}

De factoranalyse kan goed geslaagd worden genoemd: voor iedere factor zijn er zowel hoge als lage ladingen en geen twee factoren hebben hoge ladingen op dezelfde variabele. Met betrekking tot de interpretatie kan het volgende worden gezegd.

Hoge scores op Fl gaan samen met een groot aandeel van de favoriete winkel, weinig winkels en weinig winkels per merk. Fl kan daarom neiging tot het kopen in veel verschillende winkels worden genoemd.

F2 vertoont ongeveer hetzelfde beeld voor het merk als F1 voor de winkel (de richting van een factor is uiteraard arbitrair, de tekens van de factorladingen kunnen evengoed tegengesteld worden genomen). $\mathrm{F} 2$ kan daarom neiging tot het kopen van veel verschillende merken worden genoemd. Huishoudingen die laag op F3 scoren veranderen vaak van merk en winkel, zonder dat ze speciaal veel merken of winkels 
hebben. Deze huishoudingen gaan blijkbaar heen en weer binnen een betrekkelijk klein aantal merken en winkels. F3 kan daarom een vibratiefactor worden genoemd.

Het belangrijkste kenmerk van huishoudingen die hoog scoren op F4, is dat bij deze huishoudingen merkverandering en winkelverandering vaak samengaan en dat ze veel van merk én winkel veranderen. F4 kan daarom ,,neiging om vaak en tegelijk van merk én winkel te veranderen" worden genoemd.

We concluderen uit deze factoranalyse, dat er in het koopgedrag met betrekking tot bier de volgende onderling onafhankelijke factoren zijn te onderscheiden: een neiging tot het kopen van veel verschillende merken, een neiging tot het kopen bij veel verschillende winkels, een neiging vaak en tegelijk van merk en winkel te veranderen en een vibratiefactor. In het koopgedrag van individuele consumenten zijn deze factoren in verschillende mate vertegenwoordigd.

De merk-winkel samenhang werd voor de twee andere produkten op analoge wijze geanalyseerd, hetgeen tot soortgelijke conclusies leidde.

\section{De invloed van marketingvariabelen}

De marketing variabelen, ook wel genoemd de elementen van de marketing mix, zijn de instrumenten waarmee de aanbieder van een produkt (fabrikant of detaillist) zijn marktbeleid voert. Het is daarom belangrijk te weten wat het effect van de marketing variabelen op de positie van een merk in de markt is.

Twee belangrijke marketing variabelen zijn prijs en reclame en in het onderzoek is getracht met behulp van regressie-analyse een inzicht te krijgen in het effect van deze variabelen op de merkkeuze. Hiertoe werd de waarnemingsperiode opgedeeld in 4-weekse perioden en werden voor iedere periode een aantal grootheden berekend als: marktaandeel, gemiddelde prijs, uitgaven aan reclame, etc. Een handicap is de beperkte lengte van de waarnemingsperiode. Het aantal waarnemingen in de regressieanalyse is daardoor slechts 22 .

Er werden verschillende functiespecificaties gehanteerd. Als voorbeeld geven we de volgende specificaties en de resultaten voor een bepaald merk fopro:

$$
M_{i}=\alpha_{0}+\alpha_{1} T_{i}+\alpha_{2} P_{i}+\alpha_{3} R_{i}^{E}+\alpha_{4} R_{i}^{C}+\alpha_{5} R_{i-1}^{E}+\alpha_{6} R_{i-1}^{C}+U_{i}
$$

waarbij:

$M_{i}=$ marktaandeel van het betreffende merk in periode $i$

$T_{i} \quad=$ trendvariabele

$\boldsymbol{P}_{\boldsymbol{i}} \quad=$ relatieve prijs van het merk (t.o.v. die van de concurrentie)

$R_{i}^{E} \quad=$ eigen reclame (gemeten aan de uitgaven in guldens) in periode $i$

$R_{i}^{C} \quad=$ reclame van concurrerende merken in periode $i$

$R_{i-1}^{E}=$ eigen reclame in de voorgaande periode

$R_{i-1}^{C}=$ concurrerende reclame in voorgaande periode

$U_{i}=$ storingsterm, waarvoor de gebruikelijke veronderstellingen worden gemaakt. 
Schatting van de regressiecoëfficiënten voor deze vergelijking leverde de volgende significante coëfficiēnten op (bij $\alpha=.05$ ):

$$
\begin{array}{lll}
\alpha_{1}=.0009 & \alpha_{3}=.0002 & R^{2}=.68 \\
\alpha_{2}=-.0041 & \alpha_{6}=-.0001 & d \text { (Durbin-Watson) }=1.89
\end{array}
$$

Hieruit kan worden geconcludeerd, dat het marktaandeel van het betreffende merk een autonome trendmatige stijging vertoont, dat het marktaandeel daalt als de relatieve prijs van het merk hoger wordt en dat de eigen reclame in de lopende periode een positieve invloed op het marktaandeel heeft, terwijl de concurrerende reclame uit de voorgaande periode een negatief effect heeft. De invloed van de marketing variabelen prijs en reclame op de merkkeuze is hier dus duidelijk aangetoond en de richting ervan is, zoals werd verwacht. De waarde van $R^{2}$ is bevredigend (vergeleken met andere studies van dit type) terwijl er geen problemen met autocorrelatie lijken te zijn. Een methodisch aspect is nog, dat - aangezien de afhankelijke variabele hier een kans is - strikt genomen de veronderstelling van constante variantie voor $U_{i}$ niet gerechtvaardigd is. Een analyse waarbij hiermee rekening werd gehouden en Cox 's [4] logaritmische transformatie werd gehanteerd leverde echter nauwelijks afwijkende resultaten op. Niet in alle gevallen waren de resultaten van de regressieanalyse zo bevredigend als de boven vermelde. Toch kon in de meeste gevallen een duidelijke invloed van prijs en/of reclame op de merkkeuze worden aangetoond.

Een ander instrument van het marktbeleid is de speciale aanbieding. Dit kan zijn: een tijdelijke prijskorting, een premium (cadeau bij de aankoop van het produkt) o.i.d. De bedoeling ervan is om consumenten te beïnvloeden in hun merkkeuze. Om een indruk te krijgen in hoeverre dit inderdaad gebeurt kan de mate van merkverandering bij aankopen met en zonder aanbieding worden vergeleken. Hieruit blijkt, dat bij bier bij $18 \%$ van de aankopen met aanbieding het merk verschillend is van dat bij de vorige aankoop. Bij bieraankopen zonder aanbieding treedt in $11 \%$ van de gevallen merkverandering op. Voor fopro zijn deze getallen respectievelijk $21 \%$ en $8 \%$, voor margarine $35 \%$ en $26 \%$. Hieruit kan worden geconcludeerd, dat speciale aanbiedingen inderdaad de merkkeuze beïnvloeden.

\section{Slotbeschouwing}

De met dit onderzoek verkregen inzichten zijn belangrijk voor de aanbieder van een produkt die een marktbeleid moet uitstippelen. Voor een niet gering deel moeten ze ook worden gezien als belangrijke informatie, benodigd voor de ontwikkeling van betere en meer integrale modellen voor merkkeuze. In dit verband kan worden opgemerkt, dat in het hier beschreven onderzoek een aantal partiële analyses zijn uitgevoerd: de invloed van eerdere aankopen, van de winkel en van de marketing variabelen.zijn alle afzonderlijk onderzocht. De resultaten maken duidelijk dat het gewenst is merkkeuzemodellen te ontwikkelen, waarin zowel de invloed van eerder gekochte merken, als van de winkel, als van de marketing variabelen simultaan is gerepresenteerd. Dit zou bijvoorbeeld kunnen door in het Lineaire Leermodel de 
parameters van dit model afhankelijk te stellen van de winkel en van de marketing variabelen. Met een dergelijk model zou rechtstreeks het effect van veranderingen in prijs, reclame e.d., op de positie van een merk in de markt kunnen worden voorspeld.

Er dient ook aandacht te worden besteed aan enkele andere belangrijke beperkingen van de huidige merkkeuzemodellen, zoals bijvoorbeeld het feit dat doorgaans slechts 2 merken in een markt kunnen worden onderscheiden en de beperking dat slechts de merkkeuze bij een aankoop en niet de gekochte hoeveelheid een rol speelt.

Voor nuttige suggesties betreffende de tekst dankt de schrijver de anonieme referent.

\section{Referenties}

[1] Anderson, T. W. en L. A. Goodman, Statistical Inference About Markov Chains, Annals of Mathematical Statistics, Vol. 28, 1957, 89-110.

[2] Bradley, J. V., Distribution-Free Statistical Tests, Prentice Hall, Englewood Cliffs, N.J. 1968.

[3] Bush, R. R. en F. Mosteller, Stochastic Models For Learning, Wiley, New York, 1955.

[4] Cox, D. R., The Analysis of Binary Data, Methuen \& Co., London, 1970.

[5] Cramer, H., Mathematical Methods of Statistics, Princeton University Press, Princeton, 1957.

[6] Kemeny, J. G. en J. L. Snell, Finite Markov Chains, Van Nostrand Company, Princeton, N.J. 1960.

[7] Massy, W. F., D. B. Montgomery en D. G. Morrison, Stochastic Models of Buying Behavior, M.I.T. Press, Cambridge (Mass.), 1970.

[8] WierengA, B., An Investigation of Brand Choice Processes, Universitaire Pers Rotterdam, Rotterdam, 1974.

[9] WirRengA, B., A Least Squares Estimation Method for the Linear Learning Model. Verschijnt in: Journal of Marketing Research. 